\title{
Сравнительная характеристика сорбентов для иммобилизации а-амилазы
}

\author{
Шкутина И.В. ${ }^{1}$, Мироненко Н.В. ${ }^{2}$, Селеменев В.Ф. ${ }^{2}$ \\ ${ }^{1}$ ФГБОУ ВО «Санкт-Петербургский государственный педиатрический медииинский университет», \\ Санкт-Петербург \\ ${ }^{2}$ ФГБОУ ВО «Воронежский государственньй университет», Воронеж
}

Поступила в редакцию 1.03.2018 г.

DOI: https://doi.org/10.17308/sorpchrom.2018.18/492

Рассмотрены закономерности адсорбционной иммобилизации гидролитического фермента $\alpha-$ амилазы на ионообменных и неионообменных сорбентах. Проведена сравнительная оценка сорбционной способности и каталитической активности носителей по отношению к ферменту в зависимости от концентрации ионов водорода и белка в растворе. Проанализировано изменение конформации белковых молекул при связывании с матрицей носителей. Установлена возможность многократного использования иммобилизованного фермента в реакции гидролиза крахмала.

Ключевые слова: $\alpha$-амилаза, ионообменник, неионогенный сорбент, иммобилизация, гетерогенный биокатализатор, каталитическая активность.

\section{Comparative characteristic of sorbents for immobilization of $\alpha$-amilase}

\author{
Shkutina I.V. ${ }^{1}$, Mironenko N.V. ${ }^{2}$, Selemenev V.F. ${ }^{2}$ \\ ${ }^{1}$ FGBOU VO St. Petersburg State Pediatric Medical University, St. Petersburg \\ ${ }^{2}$ FGBOU VO Voronezh State University, Voronezh
}

A comparative evaluation of the immobilization of the hydrolytic enzyme $\alpha$-amylase on aminocarboxyl granular ANKB-2, ANKB-50 and fibrous K-3, AK-22-1, X-1 ion exchangers, granular MN-500 and fibrous K-1 sulfocation exchangers, nonionic sorbent Styrosorb was carried out. Methods of sorption analysis and photometry have been used to study the sorption capacity of carriers with respect to the enzyme depending on the concentration of hydrogen ions and protein in solution. It is shown that the best protein sorption is observed at $\mathrm{pH} 4.5-5.0$, in the field of the isoelectric point of the protein. At a given $\mathrm{pH}$, the catalytic activity of enzyme preparations was also of the greatest value.

During the adsorption immobilization of protein on the ion exchangers under study, supramolecular complexes can be realized due to hydrogen, electrostatic, van der Waals, hydrophobic interactions. During the immobilization of $\alpha$-amylase on super-crosslinked sorbents (MN-500, Stirosorb), the leading role is played by hydrophobic interactions that lead to the appearance of $\pi$ - $\pi$-electron interaction between the sorbat and the sorbent. The maximum catalytic activity of the obtained heterogeneous biocatalysts is $89 \%$ for the amylase-AK-22-1 complex and 92\% for the amylase-Stirosorb complex from the activity of the native enzyme. It was noted that during the immobilization of $\alpha$-amylase, the sorbent-water and sorbat-water interaction processes to some extent compete with the parallel sorbent-sorbat interaction process.

Using the IR method, the absorption spectra of a free and immobilized enzyme are compared. The ratio of the types of the secondary structure ( $\alpha$-helix, $\beta$-layers, disordered structure) is calculated according to the Bouguer-Lambert-Beer law, using the Amid II band, the oscillation type is $v_{\mathrm{II}}$. It was stated that when the protein is bound to the carriers, the structure of the enzyme changes insignificantly. It was found that heterogeneous biocatalysts immobilized on non-ionogenic Stirosorb sorbent can be used for 14 cycles in the starch

Шкутина и др. / Сорбционные и хроматографические процессы. 2018. Т. 18. № 2 
hydrolysis reaction. As a result of the studies, the prospective application of the studied non-ionic supercrosslinked polymer Stirosorb and the fibrous aminocarboxylic polyelectrolyte AK-22-1 for the immobilization of $\alpha$-amylase has been proved.

Keywords: $\alpha$-amylase, ion exchanger, non-ionic sorbent, immobilization, heterogeneous biocatalyst, catalytic activity.

\section{Введение}

С каждым годом увеличивается объем выпускаемых ферментных препаратов, растет ассортимент и область их применения. Особое значение для фармакологии, медицины, пищевой промышленности имеют амилолитические ферменты. В частности, фермент $\alpha$-амилаза ( $\alpha$-1.4-глюкан-4-глюканогидролаза, К.Ф. 3.2.1.1) гидролизует $\alpha-1.4$ - гликозидные связи в крахмале и гликогене с образованием мальтозы и глюкозы.

Основой для создания принципиально новых биотехнологических процессов, альтернативных традиционным химическим технологиям, могут служить гетерогенные биокатализаторы, полученные в результате иммобилизации ферментов. Длительность сохранения каталитической активности и ряд свойств ферментов определяются правильностью выбора носителя, метода и условий проведения иммобилизации. При этом допускается прикрепление фермента только за счет функциональных групп, не входящих в его активный центр и не участвующих в образовании фермент-субстратного комплекса. При выборе носителя должна учитываться безвредность компонентов носителя, его химическая стабильность, доступность, легкость регенерации, возможность многократного использования, инертность матрицы по отношению к микробной флоре [1].

Целью настоящей работы является сравнительная оценка адсорбционной иммобилизации $\alpha$-амилазы Aspergillus awamori на ионогенных и неионогенных сорбентах, впервые использованных нами для иммобилизации энзимов [2-4].

\section{Эксперимент}

В работе был исследован ферментный препарат $\alpha$-амилаза Aspergillus awamori («Диаэм», Москва). В качестве носителей для иммобилизации $\alpha$-амилазы использовались аминокарбоксильные гранульные АНКБ-2, АНКБ-50 и волокнистые К-3, AК-22-1, X-1 ионообменники, гранульный MN-500 и волокнистый К-1 сульфокатионообменники, неионогенный сорбент Стиросорб. Подготовку сорбентов к иммобилизации осуществляли путем кондиционирования и переводом полиэлектролитов в нужную ионную форму. Неионогенный Стиросорб заливали ацетоном и выдерживали до набухания. Затем отмывали от ацетона дистиллированной водой до его полного отсутствия в промывных водах. Подготовленный сорбент хранили под слоем воды в набухшем состоянии.

Для получения изотерм сорбции использовали метод переменных концентраций [5]. Навески сорбента $(1.0000 \pm 0.0002$ г) приводили в контакт с растворами $\alpha$-амилазы с концентрациями $0.1 \div 5.0 \cdot 10^{-2}$ ммоль/дм ${ }^{3}$. Соотношение раствор/сорбент было постоянным и составляло 100/1. Растворы готовили на основе ацетатного буфера с разным значением $\mathrm{pH}$ среды. В ходе предварительных кинетических опытов было установлено, что время достижения равновесия составляет 120 мин. Эксперименты проводили при 293 К. Концентрацию веществ в равновесном растворе определяли спектрофотометрически по модифицированному методу Лоури [6]. Количество вещества в фазе сорбента вычисляли по разности концентраций исходного и равновесного растворов. Десорбция белка в буферные 
растворы составляла не более $5 \%$. Каталитическую активность $\alpha$-амилазы измеряли фотометрическим методом. Стандартное отклонение полученных результатов не превышало величину 0.01 [7-9].

ИК спектры образцов $\alpha$-амилазы снимали на ИК-спектрометре Bruker VERTEX-70 в интервале частот 400-4000 $\mathrm{cm}^{-1}$. Интерпретацию спектров проводили, используя литературные данные [10].

\section{Обсуждение результатов}

При взаимодействии фермента с носителем одним из определяющих факторов является $\mathrm{pH}$ среды. В активный центр $\alpha$-амилазы Aspergillus awamori входят радикалы аспарагиновой кислоты ( $\left.\mathrm{pK}_{\mathrm{a}} 3.2\right)$ и гистидина ( $\left.\mathrm{pK}_{\mathrm{b}} 6.9\right)$, а также $\mathrm{Ca}^{2+}$ связывающий центр, который играет существенную роль в поддержании стабильности белковой макромолекулы. В каталитическом центре $\alpha$-амилазы пара карбоксилат-имидазолий функционирует по типу кислотно-основного катализа. Роль электрофильной группы отводится имидазолию, в то время как карбоксилат-ион выполняет функцию нуклеофила. Активный центр обладает высокой лабильностью, при этом различные типы взаимодействий, сбалансированные между собой, охватывают всю молекулу в целом. Нарушение этого равновесия может привести к существенным изменениям топологии функциональных групп в активном центре [11]. Выявлено, что максимальная сорбция $\alpha$-амилазы для всех сорбентов происходит в области изоэлектрической точки белка при $\mathrm{pH}$ 4.5-5.0 (рис. 1) и сохранении ферментными препаратами наибольшего значения каталитической активности.

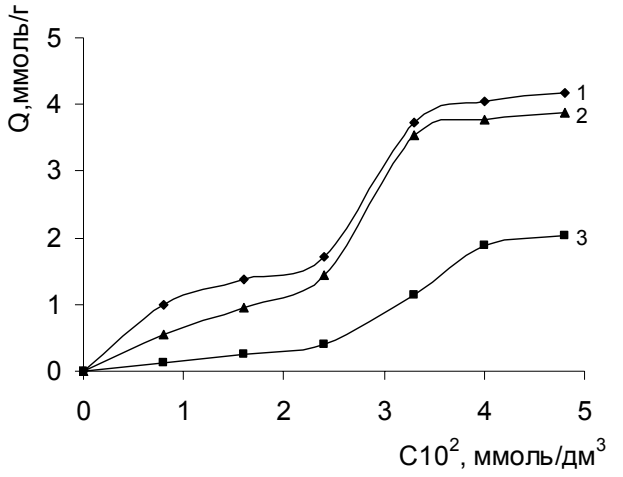

Рис. 1. Зависимость количества сорбированной $\alpha$-амилазы $(\mathrm{Q}$, ммоль/г) от $\mathrm{pH}$ равновесного раствора : 1 - Стиросорб; 2 - АК-22-1; 3 - АНКБ-2.

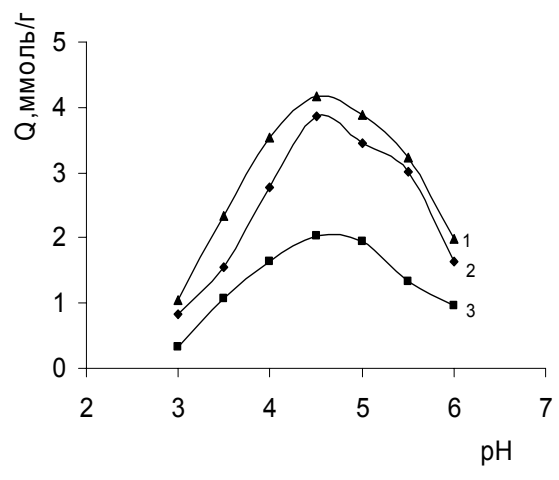

Рис. 2. Изотермы сорбции -амилазы при рН 4.7: 1 - Стиросорб; 2 - АК-22-1; 3 - АНКБ-2. С - исходная концентрация белка в растворе, ммоль / дм³.

При адсорбционной иммобилизации белка на рассматриваемых ионообменниках могут образовываться супрамолекулярные комплексы за счет водородных, электростатических, вандер-ваальсовых, гидрофобных взаимодействий [12]. На рис.2 представлены изотермы сорбции $\alpha$-амилазы при $\mathrm{pH}$ 4.7. При достаточно низких концентрациях фермента в растворе процесс адсорбции на ионообменниках, вероятно, осуществляется в результате ионного обмена. Дальнейшее распределение белка в фазе носителя происходит, главным образом, за счет неионообменного взаимодействия молекул сорбата друг с другом. Следствием этой ассоциации является образование на поверхности сорбента полимолекулярных слоев. При иммобилизации значительная роль принадлежит также растворителю, с учетом его количества, изменения состояния в процессе сорбции и перераспределения между фазами. Процессы взаимодействия сорбент - вода и 
сорбат - вода в определенной степени конкурируют с параллельным процессом взаимодействия сорбент - сорбат.

Проведенные исследования показали, что на волокнистых носителях сорбируется в 1.5-3 раза больше количества белка, чем на гранульных ионообменниках (табл.1). Волокнистые сорбенты «Фибан» обладают высокоразвитой поверхностью, высокой механической прочностью, химической и осмотической стойкостью [13]. Полученные биокатализаторы, благодаря своей физической форме и свойствам, могут быть использованы в непрерывных биотехнологических процессах, как, например, в реакторах колоночного типа. Преимуществом является и тот факт, что матрица волокнистых носителей защищает ферменты от инактивирующего воздействия микроорганизмов.

Таблица 1. Характеристики адсорбционной иммобилизации $\alpha$-амилазы на носителях различной структуры

\begin{tabular}{|c|c|c|c|c|c|c|c|}
\hline Сорбент & Q, ммоль/г & $\begin{array}{c}\text { А, } \\
\text { Ед/мг }\end{array}$ & $\eta, \%$ & Сорбент & $\begin{array}{c}\mathrm{Q}, \\
\text { ммоль/г }\end{array}$ & $\begin{array}{c}\mathrm{A}, \\
\text { Ед/мг }\end{array}$ & $\eta, \%$ \\
\hline АНКБ-2 & 2.03 & 1600 & 64 & $\mathrm{X}-1$ & 2.72 & 1925 & 77 \\
\hline АНКБ-50 & 1.34 & 1425 & 57 & АК-22-1 & 3.87 & 2225 & 89 \\
\hline К-1 & 3.62 & 2025 & 81 & Стиросорб & 4.18 & 2300 & 92 \\
\hline К-3 & 3.75 & 1775 & 73 & MN-500 & 4.05 & 2100 & 84 \\
\hline
\end{tabular}

Q - количество сорбированной $\alpha$-амилазы., ммоль $/ г ;$ А - каталитическая активность иммобилизованной $\alpha$-амилазы; $\eta$ - процент сохранения активности гетерогенного биокатализатора, $\%$.

Гидрофобные взаимодействия играют определяющую роль при иммобилизации $\alpha$-амилазы на сверхсшитых сорбентах (MN-500, Стиросорб). Высокая удельная поверхность ( $\mathrm{S}_{\text {уд. }}=910-950 \mathrm{~m}^{2} / \mathrm{c}$, размер частиц $-60-80$ мкм) способствует большему, чем у «слабосшитых» полистиролов проявлению $\pi-\pi-$ электронного взаимодействия между сорбатом и сорбентом [14]. При использовании носителей данного типа появляется возможность располагать необходимым образом в пространстве структурные единицы, а также центры связывания и функциональные группы белка. Предполагается, что при связывании $\alpha$-амилазы происходит формирование $\pi$ - $\pi$-электронного взаимодействия между гетероциклами гистидина, триптофана, бензольным кольцом тирозина и бензольными кольцами носителей. Многие боковые группы аминокислот не заряжены, при этом они стремятся объединиться друг с другом. К аминокислотам, содержащим неполярные алифатические и ароматические боковые группы, относятся аланин, валин, лейцин, изолейцин и фенилаланин, которые также вступают в гидрофобные взаимодействия с сорбентом. Из всех рассматриваемых носителей на неионогенном Стиросорбе сорбируется наибольшее количество белка - 4.18 ммоль/г, при этом активность иммобилизованной $\alpha$-амилазы составляет $92 \%$ от активности нативного фермента.

Одним из определяющих требований, предъявляемых к разным видам иммобилизации, является условие сохранения нативной конформации фермента. Для определения влияния иммобилизации на структуру белка проводился сравнительный анализ ИК спектров свободного и иммобилизованного фермента. Было рассчитано соотношение типов вторичной структуры по закону Бугера-Ламберта-Бера, с использованием полосы Амид II, тип колебания - v тов расчета, конформация иммобилизованного белка на носителях различной природы изменяется в незначительной степени (табл.2). 
Таблица 2. Содержание типов вторичной структуры свободной и иммобилизованной $\alpha$-амилазы в процентах (\%)

\begin{tabular}{|c|c|c|c|c|c|}
\hline \multirow{2}{*}{ Конформация } & \multirow{2}{*}{$v, \mathrm{~cm}^{-1}$} & \multirow{2}{*}{$\begin{array}{c}\text { Свободная } \\
\alpha \text {-амилаза }\end{array}$} & \multicolumn{3}{|c|}{ Иммобилизованная $\alpha$-амилаза } \\
\cline { 4 - 6 } & & 29 & 26 & 27 & 20 \\
\hline$\alpha$-спираль & 1521 & 28 Анорорб & АК-22-1 & АНКБ-2 \\
\hline$\beta$-слои & 1534 & 32 & 28 & 30 & 23 \\
\hline $\begin{array}{c}\text { Неупорядоченная } \\
\text { структура }\end{array}$ & 1548 & 39 & 46 & 43 & 57 \\
\hline
\end{tabular}

Важным преимуществом гетерогенных биокатализаторов по отношению к нативным ферментам является возможность их повторного применения. В работе было проведено исследование цикличности действия гетерогенного биокатализатора. Для этого носитель с иммобилизованным ферментом (100 мг) помещали в пробирки с субстратом (10 $\mathrm{cm}^{3} 5 \cdot 10^{-4} \mathrm{M}$ раствора крахмала) и проводили гидролиз, меняя через каждый час субстрат. Установлено, что гетерогенный биокатализатор $\alpha$ амилаза-Стиросорб может быть использован в среднем в течение 14 циклов (рис. 3).

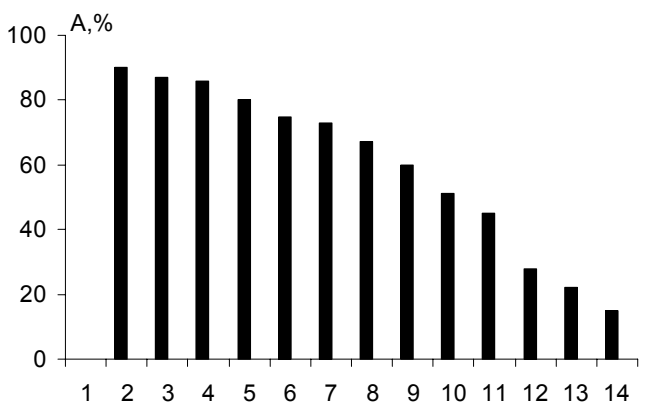

Рис. 3. Кратность использования иммобилизованной на Стиросорбе $\alpha$-амилазы в реакции гидролиза крахмала.

А - активность (\% от максимальной); n - количество реакционных циклов.

Отмечено, что полученные ферментные препараты при температуре хранения $0-2{ }^{\circ} \mathrm{C}$ сохраняли свою каталитическую активность практически неизменной в течение 1 года, что еще раз свидетельствует об эффективности предложенного способа иммобилизации.

\section{Заключение}

Определены оптимальные условия адсорбционной иммобилизации $\alpha-$ амилазы на исследуемых гранульных и волокнистых сорбентах: $\mathrm{pH}$ - 4.5-5.0, концентрация сорбата - $4.5 \div 5.0 \cdot 10^{-2}$ ммоль/дм ${ }^{3}$. Предлагаемый метод иммобилизации не требует предварительной активации носителя, гетерогенные биокатализаторы обладают высокой удельной активностью и могут быть неоднократно использованы в циклах расщепления углеводов. Полученные в работе данные подтверждают целесообразность использования для иммобилизации $\alpha-$ амилазы неионогенного сорбента Стиросорб и аминокарбоксильного полиэлектролита АК-22-1.

\section{Список литературы}

1. Варфоломеев С.Д. Химическая энзимология. М. Академия. 2005. 472 с.
2. Шкутина И.В., Стоянова О.Ф., Селеменев В.Ф., Григорьева Г.А. // Журнал 
физической химии. 2001. Т.75. № 11. С. 20082010.

3. Шкутина И.В., Стоянова О.Ф., Селеменев В.Ф. // Журнал прикладной химии. 2001. T. 74. № 5. C. 869-871.

4. Шкутина И.В., Стоянова О.Ф., Селеменев В.Ф. // Химия растительного сырья. 2012. № 2. C. 27-31.

5. Селеменев В.Ф. и др. Практикум по ионному обмену. Воронеж. Изд-во Воронеж. гос. у-та. 2004. 160 c.

6. Chibata I. // Pure and Appl.Chem. 1978. Vol. 50. No 7. pp. 667-675.

7. Селеменев В.Ф., Стоянова О.Ф., Шкутина И.В. Патент РФ. №2181770. 2002.

8. Селеменев В.Ф. Стоянова О.Ф., Шкутина И.В. Патент РФ. № 2204600. 2003.

9. Шкутина И.В., Мироненко Н.В., Стоянова О.Ф., Селеменев В.Ф. // Журнал прикладной химии. 2012. Т. 85. № 6. С. 1017-1019.

\section{References}

1. Varfolomeev S.D., Himicheskaja jenzimologija, M., Akademija, 2005, 472 p.

2. Shkutina I.V., Stojanova O.F., Selemenev V.F., Grigor'eva G.A., Journal of Physical Chemistry, 2001, Vol.75, No 11, pp.2008-2010.

3. Shkutina I.V., Stojanova O.F., Selemenev V.F., Journal of Applied Chemistry, 2001, Vol. 74., No 5, pp. 869-871.

4. Shkutina I.V., Stojanova O.F., Selemenev V.F., Chemistry of Plant Raw Materials, 2012, No 2, pp. 27-31.

5. Selemenev V.F. et al., Praktikum po ionnomu obmenu. Voronezh, Izd-vo Voronezh. gos. u-ta, 2004, $160 \mathrm{p}$.

6. Chirgadze Ju.N. Infrakrasnye spektry i struktura polipeptidov i belkov. M., Nauka, $1965,136 \mathrm{p}$.

7. Selemenev V.F., Stojanova O.F., Shkutina I.V. Patent RF, no. 2181770, 2002.

8. Selemenev V.F., Stojanova O.F., Shkutina I.V. Patent RF, no. 2204600, 2003.

Шкутина Ирина Викторовна - к.б.н., доцент кафедры общей и медицинской химии, СанктПетербургский государственный педиатрический медицинский университет, Санкт-Петербург

Мироненко Наталья Владимировна, к.х.н., ассистент кафедры аналитической химии, Воронежский государственный университет, Воронеж

Селеменев Владимир Федорович - д.х.н., профессор, заведующий кафедры аналитической химии, Воронежский государственный университет, Воронеж
10. Чиргадзе Ю.Н. Инфракрасные спектры и структура полипептидов и белков. М. Наука. $1965.136 \mathrm{c}$.

11. Karzuya H., Michio K., Yoshiki M. // Protein Eng. 1999. Vol. 12. No 10. pp. 819-824.

12. Лен Ж.-М. Супрамолекулярная химия. Новосибирск. Наука. 1998. 334 с.

13. Солдатов В.С., Марцинкевич Р.В., Покровская А.И., Шункевич А.А. // Журнал прикладной химии. 1994. Т. 67. № 10. С. 1644-1647.

14. Цюрупа, М.П. // Высокомолекулярные соединения. 1991. Т(А). 33. № 12. С.26452651.

15. Шкутина И.В., Стоянова О.Ф., Ковалева Т.А. и др. // Сорбционные и хроматографические прочессы. 2007. Т.7. № 1. С. 271-275.

9. Shkutina I.V. Mironenko N.V., Stojanova O.F., Selemenev V.F., Journal of Applied Chemistry, 2012, Vol. 85, No 6, pp.1017-1019.

10. Chibata I., Pure and Appl. Chem., 1978, Vol. 50, No 7, pp. 667-675.

11. Karzuya H., Michio K., Yoshiki M. Protein Eng., 1999, Vol. 12, No 10, pp. 819-824.

12. Len Zh.-M., Supramolekuljarnaja himija. Novosibirsk, Nauka, 1998, 334 p.

13. Soldatov V.S., Marcinkevich R.V., Pokrovskaja A.I., Shunkevich A.A., Journal of Applied Chemistry, 1994, Vol. 67, No 10, pp.1644-1647.

14. Cjurupa, M.P., High-molecular Compounds, 1991, Vol.(A).33, No.12, pp.26452651.

15. Shkutina I.V., Stojanova O.F., Kovaleva T.A. et al., Sorbtsionnye i khromatograficheskie protsessy, 2007, Vol. 7, No 1, pp. 271-275.

Shkutina Irina V. - assistant professor of general and medical chemistry, State Pediatric Medical University, St. Petersburg, e-mail: irn55@mail.ru

Mironenko Nataliay V. - assistant of analytical chemistry department of chemical faculty, Voronezh State University, Voronezh, e-mail: natashamir@yandex.ru

Selemenev Vladimir V. - doctor of science, professor, head of Department of analytical chemistry, chemical faculty, Voronezh State University, Voronezh 